\title{
Effects of hypoxia on an estuarine predator-prey interaction: foraging behavior and mutual interference in the blue crab Callinectes sapidus and the infaunal clam prey Mya arenaria
}

\author{
David L. Taylor *, David B. Eggleston \\ North Carolina State University, Department of Marine, Earth, and Atmospheric Sciences Box 8208, Raleigh, \\ North Carolina 27695-8208, USA
}

\begin{abstract}
The effects of hypoxia on trophic interactions could vary dramatically depending on whether the benthos is experiencing the onset of a hypoxic event (decreasing dissolved oxygen concentrations from normoxia), or its dissipation (increasing dissolved oxygen concentrations from hypoxia). Predator-prey dynamics between the blue crab Callinectes sapidus and an infaunal clam prey Mya arenaria were examined to assess the impact of hypoxia upon predator foraging rates and prey mortality. Laboratory experiments quantified the behavioral response of $M$. arenaria to varying dissolved oxygen levels through the analyses of (1) sediment burial depth, and (2) siphon extension above the sediment surface. Moreover, the functional response (relationship between predator consumption rates and prey density) of single and 2 adult blue crabs to 2 densities of $M$. arenaria ( 6 and 24 clams tank $\mathrm{k}^{-1}$ ) was examined across 3 dissolved oxygen treatments: (1) normoxia ( $\left.\geq 6.0 \mathrm{mg} \mathrm{DO}^{-1}\right)_{i}(2)$ moderate hypoxia ( 3.0 to $4.0 \mathrm{mg} \mathrm{DO} \mathrm{l}^{-1}$ ), subsequent to clam acclimation at high oxygen conditions ( $\left.\geq 6.0 \mathrm{mg} \mathrm{DO}^{-1}\right)_{\text {) }}$ and (3) moderate hypoxia (3.0 to $4.0 \mathrm{mg} \mathrm{DO}^{-1}$ ), subsequent to clam acclimation at low oxygen conditions $\left(\leq 1.5 \mathrm{mg} \mathrm{DO} \mathrm{l}^{-1}\right) . M$ arenaria sediment burial depth decreased and siphon extension increased during exposure to severe hypoxia. Initiation of moderate hypoxia following normoxia altered blue crab foraging behavior from a destabilizing, type II functional response, to a partially stabilizing, type I functional response. Conversely, blue crabs exhibited a type II functional response under moderate hypoxia subsequent to clam exposure to severe hypoxia. Therefore, low dis solved oxygen concentrations appear to affect the predator-prey interaction between $C$. sapidus and $M$. arenaria by either hindering blue crab foraging, or alternatively, increasing clam vulnerability by altering their siphon extension and depth distribution within the sediment column. Moreover, the inclusion of a second blue crab in experimental trials further modified functional responses through both mutual interference and agonistic behavior or cooperative foraging between predators. The collective results indicate that fluctuations in dissolved oxygen concentrations, as well as both predator and prey density, must be examined jointly to understand their impact upon predator-prey dynamics in marine systems.
\end{abstract}

KEY WORDS: Hypoxia - Trophic dynamics - Callinectes sapidus - Blue crab - Mya arenaria Predatorprey interaction - Functional response $\cdot$ Mutual interference

\section{INTRODUCTION}

The ecological impacts of hypoxia and anoxia in marine environments can be extensive but difficult to

\footnotetext{
- Present address: Graduate School of Oceanography, University of Rhode Island, Narragansett, Rhode Island 02882, USA.E-mail: dtaylor@gso.uri.edu
}

evaluate due to the inherent variability of natural biological communities, which respond continuously to a multitude of biological and environmental factors (Sandberg 1994). Nevertheless, severe oxygen deficiency in estuarine and coastal waters is one of the few environmental perturbations that leads to massive mortality of benthic organisms (Sandberg 1994, reviewed by Diaz \& Rosenberg 1995 and refer- 
ences therein). Even if the benthic community does not suffer extensive mortality, functionally important biological interactions such as predator-prey relationships may be fundamentally altered (Breitburg et al. 1994, Sandberg 1994, Nestierode \& Diaz 1998). Although chronic and large-scale hypoxia is prevalent in estuaries worldwide, little information exists on its direct and indirect effects on benthic predator-prey dynamics.

Species inhabiting oxygen-depleted waters vary considerably in their responses to hypoxia. For example, physiological and behavioral responses to oxygen deficiency are highly dependent upon the magnitude, duration, and frequency of hypoxia, and the life-history stage and age of the exposed species (Breitburg 1992, Diaz \& Rosenberg 1995). Additionally, most species of marine macroinvertebrates exhibit different tolerances to hypoxia depending upon their taxonomic position (Rosenberg et al. 1991, Desprez et al. 1992, Diaz \& Rosenberg 1995). Benthic macrofaunal species that are most resistant to prolonged exposure to severe hypoxia are bivalves and gastropods, followed by polychaetes, echinoderms, and crustaceans (Hagerman \& Uglow 1985, Kapper \& Stickle 1987. Rosenberg et al. 1991, Diaz \& Rosenberg 1995). These taxonomic patterns of tolerance to hypoxia correspond to differences in activity level and metabolic rate (Stickle et al. 1989, Diaz \& Rosenberg 1995). For example, sessile and infaunal species generally have a high tolerance to anoxia and hypoxia, due in part to a reduction in activity and hence energy use (Stickle et al. 1989). Conversely, more mobile organisms, such as crustaceans, are less effective in suppressing metabolic rates during exposure to hypoxia, and therefore exhibit a lower capacity for anaerobic metabolism, which in turn leads to a decreased tolerance to oxygen depletion (Stickle et al. 1989, Das \& Stickle 1993, 1994)

A progression of hierarchical shifts in an organism's behavior occurs with the onset of hypoxia (Diaz \& Rosenberg 1995). The first response to declining oxygen concentrations is an increase in ventilation rates that facilitates more efficient oxygen extraction from the surrounding water (Batterton \& Cameron 1978, DeFur et al. 1990). Organisms that are mobile begin to migrate away from oxygen depleted areas when concentrations fall below $3.0 \mathrm{mg} \mathrm{DO} \mathrm{l}^{-1}$ (Loesch 1960, May 1973, Renaud 1986, Pihl et al. 1991, Das \& Stickle 1993, 1994). For example, certain species of demersal fish and crustaceans migrate from relatively deep, hypoxic waters towards more oxygenated shoreward areas (Pihl et al. 1991). Moreover, demersal fish and crustaceans may exhibit vertical escape behavior towards oxygenated surface waters. For example, anecdotal observations by fishermen suggest that blue crabs ex- hibit vertical migration from hypoxic and anoxic bottom waters.

Sessile and infaunal species, unable to avoid or escape oxygen-depleted waters, initiate a series of responses to hypoxia according to its severity (Diaz \& Rosenberg 1995). Typically, feeding and other activities unrelated to ventilation will decrease to reduce metabolism (Diaz \& Rosenberg 1995). Infaunal species capable of limited mobility may also attempt an escape response by migrating vertically toward the sediment surface (Trevallion 1971, Jørgensen 1980, Diaz \& Rosenberg 1995). Numerous studies propose that many species of bivalves, echinoderms, and annelids will leave the refuge provided by soft sediments as oxygen concentrations decrease to near lethal levels (Jørgensen 1980, Rosenberg et al. 1991, Nilsson \& Rosenberg 1994, Diaz \& Rosenberg 1995). Some bivalves also react to hypoxia by extending their siphons upward into the water column in search of higher oxygen concentrations (Jørgensen 1980, Diaz \& Rosenberg 1995). As a consequence of the redistribution of macrobenthic fauna in response to hypoxia, the population structure of marine benthic communities may also be drastically altered (Jørgensen 1980, Breitburg 1992, Pihl et al. 1992, Diaz \& Rosenberg 1995). If hypoxia persists or intensifies, selective mortality may occur, first among the more sensitive taxa such as crustaceans and echinoderms and, eventually, in even the most tolerant species (Diaz \& Rosenberg 1995).

The prevalence of hypoxia in estuarine habitats is extremely dynamic spatially and temporally due to wind-driven upwelling events (Haas 1977, Officer et al. 1984, Blumberg \& Goodrich 1990). Bottom waters can change nearly instantaneously from normoxic to hypoxic conditions, or vice versa, and are sustained episodically (minutes/hours) or chronically (weeks/ months) (Breitburg 1992, Nestlerode \& Diaz 1998, Taylor 1998). The effects of hypoxia on trophic interactions, and more specifically on the behavior of mobile epibenthic predators foraging upon infaunal prey, may vary dramatically depending on whether the benthos are experiencing declines in oxygen concentrations from normoxia to hypoxia, or an increase in oxygen concentrations from hypoxia to normoxia.

This paper describes the effects of episodic hypoxia on a key estuarine predator-prey relationship between the blue crab Callinectes sapidus and the infaunal clam prey Mya arenaria. We examined the behavioral response of $M$. arenaria prey to moderate and severe hypoxia under laboratory conditions by quantifying (1) sediment burial depth, and (2) siphon extension into the water column. Additionally, predator-prey experiments assessed foraging behavior and mutual interference in C. sapidus to ascertain whether or not hypoxia alters predator-prey dynamics 


\section{Functional response}

\section{Analysis of functional responses}

The relationship between the consumption rate of a predator and the density of its prey is known as the predator's functional response. The type of functional response may identify potential behavioral mechanisms leading to oscillations in prey populations (Murdoch \& Oaten 1975), or to the local extinction or persistence of certain prey (Lipcius \& Hines 1986, Eggleston 1990a, Eggleston et al. 1992). Examination of a predator's functional response is a powerful, quantitative method for examining predator-prey dynamics under varying environmental conditions (Lipcius \& Hines 1986, Eggleston 1990b, Eggleston et al. 1992), and can provide an effective framework for identifying the importance of predation in regulating marine and estuarine benthic communities (Abrams et al. 1990).

When the number of prey consumed is plotted against prey density, a continuum of patterns may emerge from which 3 primary types of functional responses are typically characterized (Holling 1959. Hassell 1978). In the type I functional response, consumption rates increase linearly with increasing prey density until reaching a plateau at satiation. Satiation occurs when a predator cannot handle prey any faster; hence, ingestion remains constant despite increasing prey density (i.e. prey mortality is density-independent) (Hassell 1978). In the hyperbolic type II functional response, inversely density-dependent consumption rates rise at a decelerating rate to an upper asymptote, reflecting increased costs or constraints associated with higher consumption rates (Hassell 1978). The type III functional response is sigmoid, demonstrating density-dependent acceleration in consumption rates at low to moderate prey densities (Hassell 1978). The acceleration in feeding rates results from increased predator efficiency in the detection or capture of prey as prey density increases (Hassell 1978). Thus, a type III functional response imparts stability to predator-prey dynamics via a relative refuge at low prey densities (Lipcius \& Hines 1986, Eggleston et al. 1992). Similarly, a type I functional response could be considered partially stabilizing to predatorprey dynamics relative to a destabilizing, type II functional response.

The ability to distinguish among functional responses may be difficult when analyses rely on predator consumption rates. When the number of prey consumed is converted to the proportion of prey eaten per predator, however, distinct differences appear among types I, II, and III functional responses. A constant mortality rate across prey densities is indicative of a type I functional response. In the types II and III functional responses there is a change from an increasing to a decreasing risk of mortality as prey density decreases, respectively. The drastic differences occurring among the functional responses at low prey densities facilitate differentiation among types I, II, and III functional responses (Lipcius \& Hines 1986, Eggleston et al. 1992). Moreover, if the 'low density' range for a particular species is known, then the difference between functional responses can be determined from as few as 2 data points within that range. For example, at low and moderate prey densities, a pattern illustrating no significant difference in proportional mortality across 2 prey densities demonstrates a density-independent, type I functional response. Conversely, significantly higher proportional mortality at low prey densities characterizes an inversely density-dependent, type II functional response, whereas a pattern of significantly lower proportional mortality at low prey densities defines a density-dependent, type III functional response (Lipcius \& Hines 1986, Eggleston et al. 1992).

\section{Factors affecting functional responses}

The aggregation of foraging predators can have a significant impact on their individual functional responses. For example, predator aggregation can promote a type II functional response by enhancing the foraging efficiency of individual predators if they are attracted to prey patches by foraging conspecifics, or when mutual attacks are more successful than individual attacks (Hassell \& May 1973, 1974, Mansour \& Lipcius 1991). Conversely, predator aggregation may regulate prey populations if predators congregate in areas of high prey density, and leave those prey patches when the rate of prey capture falls below a threshold necessary to sustain constant foraging efforts (Mansour \& Lipcius 1991). Aggregative responses could also promote agonistic interactions and mutual interference among predators, which could adversely affect either their searching efficiency or feeding rates (Mansour \& Lipcius 1991, Clark 1997). The combination of predator aggregation and mutual interference may stabilize predator-prey dynamics by promoting a type III functional response. A type III functional response could provide a partial refuge for prey in low density patches, as well as promote dispersal of predators from patches in which prey have been heavily exploited (Mansour \& Lipcius 1991). In a study that examined the density-dependent foraging of Callinectes sapidus upon the infaunal clam Macoma balthica, Mansour \& Lipcius (1991) found evidence that mutual interference and intraspecific aggression between crabs increased with predator density. Agonistic interactions between 
blue crabs-which resulted in mortality, carapace wounds, and loss of appendages-also promoted the maintenance of a density-dependent refuge (type III functional response) for large infaunal clams, rather than leading to a destabilizing, type II functional response (Mansour \& Lipcius 1991).

Changes in abiotic and biotic factors can also significantly alter the functional response of a predator (Lipcius \& Hines 1986, Eggleston 1990a, Sandberg 1994). For example, oxygen-deficient conditions can affect predator-prey interactions by altering spatiotemporal abundance patterns of both predator and prey. Moreover, the varying physiological responses by predators and prey to low dissolved oxygen concentrations potentially enhance or impede predation efficiency (Gade 1983, Breitburg et al. 1994). Hypoxic conditions could be beneficial to a predator if the primary effect were to increase the vulnerability of its prey. For example, when severe hypoxia forces infaunal species to emerge from the sediment to the substrate-seawater interface, it increases their vulnerability to predators able to exploit hypoxic areas (Jørgensen 1980, Pihl et al. 1992, Nestlerode \& Diaz 1998). Additionally, bivalves that respond to hypoxia by extending their siphons above the sediment surface increase their susceptibility to sublethal predation (i.e. siphon cropping and nipping) by epibenthic foragers (Jorgensen 1980, Pihl et al. 1992, Nestlerode \& Diaz 1998). In a study on the diet of bottom-feeding fish and crustaceans, Pihl et al. (1992) found that predators achieved optimal prey exploitation during or immediately after hypoxia as a result of increased prey availability due to changes in the depth distribution of infaunal organisms in the sediment.

Low oxygen concentrations can also have a detrimental effect on predators that require higher oxygen levels for efficient prey capture than their prey require for efficient escape behavior. For example, Sandberg (1994) determined that the foraging efficiency of the predatory isopod Saduria entomon on the amphipods Corophium volutator and Bathyporeia pilosa decreased significantly as a function of decreased dissolved oxygen levels. Because the physiology and behavior of marine predators and prey varies to such a large extent in response to depleted oxygen levels (Stickle et al. 1989, Breitburg 1992), hypoxic events can lead to either increased or decreased prey capture. thereby affecting predators' functional responses and ultimately food web dynamics within marine and estuarine communities.

\section{Predator-prey system}

Predator-prey interactions are extremely complex in many benthic communities due to the dominance of generalized, omnivorous predators and the absence of a single, competitively dominant prey species capable of monopolizing resources (Virnstein 1977, Hines et al. 1990, Eggleston et al. 1992). In certain marine and estuarine systems, however, trophic complexities can be simplified to a relatively few strong interactions (Paine 1980, Menge 1983, Eggleston et al. 1992, Wooten 1994).

The blue crab Callinectes sapidus Rathbun (Arthropoda: Crustacea: Portunidae) is an ecologically and commercially important species that inhabits estuarine and coastal waters along the Atlantic and Gulf coasts of North America (Van Engel 1958, Laughlin 1982, Williams 1984). Serving as an epibenthic omnivore and prey resource, blue crabs are critical to energy transfer across trophic levels within estuarine and coastal ecosystems (Baird \& Ulanowicz 1989). Despite its characterization as an omnivore (Laughlin 1982, Moksnes et al. 1997), blue crabs preferentially consume bivalves such as the infaunal, soft-shelled clam Mya arenaria (Lipcius \& Hines 1986).

Mya arenaria Linnaeus (Mollusca: Bivalvia: Myacidae) is an abundant, deep-burrowing (ca 10 to $30 \mathrm{~cm}$; Hines \& Comtois 1985) suspension-feeding clam that occurs predominantly in sandy-mud habitats of temperate waters of the western North Atlantic coast (Hines \& Comtois 1985). Blue crabs and $M$. arenaria exhibit discordant population cycles. For example, in Chesapeake Bay, USA, M. arenaria typically exhibit 2 recruitment pulses: a relatively weak winter settlement pulse, and a marked spring pulse after which the population declines rapidly in July and August at the time of increased crab abundance and intense predation (Blundon \& Kennedy 1982a,b).

The contrasting oscillations that occur between populations of predatory Callinectes sapidus and Mya arenaria strongly suggest that blue crabs are capable of limiting the abundance of soft-shelled clams (Seitz unpubl.). Nevertheless, large adult clams persist at great burial depths (ca 20 to $30 \mathrm{~cm}$; Hines \& Comtois $1985)$ and low densities $\left(0.2\right.$ to 19 clams $\mathrm{m}^{-2}$; Hines et al. 1990) within sandy but not muddy habitats. The low density refuge for $M$. arenaria in sand is attributed to C. sapidus exhibiting a density-dependent, type IIl functional response to $M$. arenaria in sandier substrates (Lipcius \& Hines 1986). Conversely, blue crabs foraging in muddy sediments exhibit an inversely density-dependent, type If functional response, which precludes a refuge at low prey densities (Lipcius \& Hines 1986). The suggested mechanism resulting in the change in predatory behavior across varying sediment compositions was an increase in crab encounter rates with clam siphons in muddy versus sandy sediments (Lipcius \& Hines 1986). Blue crabs search for prey by probing the substrate with the tips of their walking 
legs (Lipcius \& Hines 1986), where chemosensory and tactile setae are located. The ease in which crabs can penetrate the surface of mud substrates with their walking legs enhances the detection of clam siphons and hence increases predation (Lipcius \& Hines 1986. Eggleston et al. 1992).

Regardless of how subtle differences in the physical structure of microhabitats alter predator-prey dynamics, the local persistence of Mya arenaria may also be affected by other environmental factors such as the occurrence of hypoxia. Low dissolved oxygen concentrations potentially alter predator-prey dynamics between Callinectes sapidus and $M$. arenaria by either hindering foraging efficiency of blue crabs, or alternatively, by increasing vulnerability of clams to crabs by altering their siphon extension and depth distribution within the sediment column. For example, C. sapidus has a greater sensitivity to hypoxia than does its clam prey (Das \& Stickle 1993, 1994, Diaz \& Rosenberg $1995)$, yet the mobility of blue crabs may allow them to follow the spatially dynamic transition zone between normoxic and hypoxic waters, and exploit clams that have been stressed by severe bouts of hypoxia (Pihl et al. 1991, Das \& Stickle 1993, 1994, Nestlerode \& Diaz 1998). The ecological impact of the initiation and relaxation of hypoxia on predator-prey dynamics between $C$. sapidus and $M$. arenaria remains unknown. Moreover, the effects of mutual interference on the functional response of blue crabs to $M$. arenaria, or how this response is further modified by dissolved oxygen levels, are unknown. Research identifying the influence of hypoxia on predator-prey relationships is critical for predicting the effects of changes in water quality on trophic interactions and food web dynamics in marine and estuarine systems.

\section{MATERIAL AND METHODS}

Collection and maintenance. Adult Callinectes sapidus were purchased from local seafood dealers or captured with an otter trawl from seagrass beds along the Neuse River, a major tributary of Pamlico Sound (North Carolina, USA). Crabs were transferred to a large outdoor holding tank ( $5 \mathrm{~m} \times 1 \mathrm{~m} \times 2 \mathrm{~m}$ ) where they were fed frozen fish and Mya arenaria ab libitum each day. Only male, intermolt crabs measuring 115 to $155 \mathrm{~mm}$ carapace width (representative of the dominant size class in Chesapeake Bay, USA; Hines et al. 1990) were used during this investigation. The use of male, intermolt crabs eliminated any potential variation in feeding due to sexual differences in behavior or chela morphology (Eggleston 1990c), and any additional stresses imposed upon molting crabs that could lead to higher rates of agonistic interactions or canni- balism (Jachowski 1973, Hines \& Ruiz 1995). M. arenaria were purchased from seafood distributors located in Auburn, Maine, USA. Only clams measuring 54 to $70 \mathrm{~mm}$ along the anterior-posterior axis and exhibiting vigorous siphon-withdrawal reflexes were used in experiments. Clams were maintained in a flowthrough seawater system, with ambient phytoplankton as a food source.

Laboratory experiments were conducted at the National Marine Fisheries Service Laboratory in Beaufort, North Carolina, USA, from July 15 to October 10 , 1998. Experimental conditions were manipulated to match local field conditions in mid-June to late August. Therefore, all experiments described below were conducted at $22-28^{\circ} \mathrm{C}, 33-37 \mathrm{psu}$, with a light:dark cycle of approximately $14: 10 \mathrm{~h}$. These conditions are typical of those encountered by estuarine organisms in temperate coastal areas of the western Atlantic during the summer, when episodes of hypoxia are most common (Officer et al. 1984).

Effects of hypoxia on clam behavior. To investigate the response of Mya arenaria to depleted oxygen concentrations, one $110 \mathrm{l}$ aquarium $(78 \mathrm{~cm} \times 60 \mathrm{~cm} \times$ $30 \mathrm{~cm}$ ) was filled with $20 \mathrm{~cm}$ of muddy, fine-sand substrate (composition: $9.7 \%$ fine sand, $75.3 \%$ very fine sand, and 15.0\% silt; $125-250,62.5-125$, and 3.9$62.5 \mu \mathrm{m}$, respectively; Folk 1974), and $20 \mathrm{~cm}$ of overlying seawater. Sediment composition and characterization (i.e. muddy, fine-sand substrate) were consistent with previous investigations that have examined predator-prey dynamics between Callinectes sapidus and $M$. arenaria (Lipcius \& Hines 1986). Three $M$. arenaria were buried approximately $10 \mathrm{~cm}$ below the sediment surface and located $20 \mathrm{~cm}$ apart from each other and the periphery of the experimental tank. Clams were allowed $24 \mathrm{~h}$ prior to the initiation of any treatment to acclimate under high oxygen conditions ( $\geq 6.0 \mathrm{mg} \mathrm{DO}^{-1}$ ) and bury to natural depths (ca 10 to $20 \mathrm{~cm}$; Hines \& Comtois 1985). After initial measurements of temperature, salinity, and dissolved oxygen, an experimental trial was initiated by rendering tank water either normoxic ( $\geq 6.0 \mathrm{mg} \mathrm{DO}^{-1}$ ), moderately hypoxic (3.0 to $4.0 \mathrm{mg} \mathrm{DO} \mathrm{^{-1 }}$ ), or severely hypoxic ( $\leq 1.5 \mathrm{mg} \mathrm{DO}^{-1}$ ) for $24 \mathrm{~h}$. Desired dissolved oxygen concentrations, monitored continuously with YSI Model 57 and YSI Model 55 handheld dissolved oxygen meters, were maintained by balancing the inflow of air and nitrogen. Four replicates of each 24 h oxygen treatment were conducted. Two response variables were quantified for $M$. arenaria: (1) burial depth and (2) siphon extension above the sediment surface. Burial depth was quantified by measuring the sediment penetration of a predetermined length of monofilament line $(11.35 \mathrm{~kg}$ test) glued to the anterior tip of the clam's shell surface prior to its introduction into 
the sediment. Siphon extension of the protruding inhalent/exhalent siphon was measured from the sediment-seawater interface to the siphon tip with a metric ruler. Burial depths and siphon extensions were averaged across the 3 clams in each trial. Mean differences in the response variables among dissolved oxygen concentrations ( $\leq 1.5 \mathrm{mg} \mathrm{DO} \mathrm{l}^{-1}, 3.0$ to $4.0 \mathrm{mg} \mathrm{DO}^{-1}$, and $\geq 6.0 \mathrm{mg} \mathrm{DO} \mathrm{^{-1 }}$ ) were analyzed with a 1 -way, fixed factor analysis of variance (ANOVA) model using dissolved oxygen concentration as a factor. The natural $\log$ of $(x+1)$ transformation was used when variances were heteroscedastic. When data transformations were unsuccessful in achieving homoscedasticity, hypotheses were rejected at alpha values lower than the p-values of $F_{\max }$ tests for homogeneity of variance (Underwood 1981). Means were contrasted with a Tukey's multiple comparison test.

Effects of hypoxia on clam behavior-real time. To gain perspective on the rate of change in burial depth and siphon extension of Mya arenaria in response to fluctuating dissolved oxygen concentrations, as indicative of field conditions, 3 clams were acclimated according to the experimental protocol described in the previous section. Following the completion of a $24 \mathrm{~h}$ high oxygen acclimation period, dissolved oxygen levels were lowered to severe hypoxia $\left(\leq 1.5 \mathrm{mg} \mathrm{DO} \mathrm{l}^{-1}\right)$ over a $2 \mathrm{~h}$ interval. Values were maintained at this level for $22 \mathrm{~h}$, after which dissolved oxygen levels were returned to normoxia ( $\geq 6.0 \mathrm{mg} \mathrm{DO} \mathrm{l}^{-1}$ ) over a $2 \mathrm{~h}$ interval and maintained for an additional $22 \mathrm{~h}$. During each of 4 replicate trials, burial depth and siphon extension were measured 4,8 , and $24 \mathrm{~h}$ after the onset of both the low and high dissolved oxygen treatments $(\leq 1.5 \mathrm{mg}$ $\mathrm{DO}^{-1}$ and $\geq 6.0 \mathrm{mg} \mathrm{DO}^{-1}$, respectively). Experimental dissolved oxygen concentrations (intensity, rate of change, and duration) simulated field data collected by the US Geological Survey, North Carolina District, from the bottom waters of the Neuse River, North Carolina, USA, during mid-August 1998 (Taylor 1998).

Blue crab satiation levels. Satiation experiments were conducted to assess maximum consumption rates of Mya arenaria by Callinectes sapidus over a $48 \mathrm{~h}$ time interval These rates were required to define an appropriate experimental period and upper density of $M$. arenaria that allowed for some degree of prey survival, and hence comparison of clam mortality rates across experimental densities. Satiation levels of blue crabs were determined by placing individual crabs within a $1 \mathrm{~m}$ diameter polyethylene tank containing 12 uniformly distributed $M$ arenaria. The experimental arena had $20 \mathrm{~cm}$ of normoxic $(\geq 6.0 \mathrm{mg}$ DO $1^{-1}$ ) seawater, but no sediment to prevent clam burial and therefore any constraints on crab searching and foraging rates. Six trials were conducted by introducing an individual blue crab for $48 \mathrm{~h}$. Satiation levels were taken as the mean rate at which $M$. arenaria were consumed (no. of clams eaten per $48 \mathrm{~h}$ ) across the 6 trials.

Effects of hypoxia and mutual interference on predator-prey dynamics. To evaluate predator responses to prey density, dissolved oxygen concentrations, and mutual interference, 2 densities of Mya arenaria 6 and 24 clams tank ${ }^{-1} ; 7.8$ clams $\mathrm{m}^{-2}$ and 31.1 clams $\mathrm{m}^{-2}$, respectively) were exposed to 2 densities of predatory Callinectes sapidus ( 1 and 2 crabs $\operatorname{tank}^{-1}$ ) across 2 dissolved oxygen concentrations (moderate hypoxia: 3.0 to $4.0 \mathrm{mg} \mathrm{DO} \mathrm{l}^{-1}$; and normoxia: $\geq 6.0 \mathrm{mg} \mathrm{DO}^{-1}$ ). The experimental densities of crabs and clams used in this investigation represent a moderate to lower range of natural densities of $C$. sapidus (Orth \& van Montfrans 1987) and $M$. arenaria (Hines et al. 1990) in Chesapeake Bay, USA. The experimental clam densities correspond to the 'low density' range for blue crabs preying on $M$. arenaria (Fig. 1).

Eight circular (1 $\mathrm{m}$ diameter) polyethylene tanks were filled with $20 \mathrm{~cm}$ of muddy, fine-sand substrate (composition: 9.7\% fine sand, $75.3 \%$ very fine sand, and $15.0 \%$ silt; $125-250,62.5-125$, and $3.9-62.5 \mu \mathrm{m}$, respectively; Folk 1974), and $20 \mathrm{~cm}$ of overlying seawater. The sediment composition chosen for this experiment was similar to that used in a previous study that identified a type II functional response by Callinectes sapidus to Mya arenaria (Lipcius \& Hines 1986). Three dissolved oxygen treatments were used: (1) normoxia ( $\geq 6.0 \mathrm{mg} \mathrm{DO} \mathrm{I}^{-1}$ ), (2) moderate hypoxia (3.0 to $4.0 \mathrm{mg} \mathrm{DO} \mathrm{l}^{-1}$ ) subsequent to $24 \mathrm{~h}$ clam acclimation at high oxygen conditions ( $\geq 6.0 \mathrm{mg} \mathrm{DO}^{-1}$ ), and

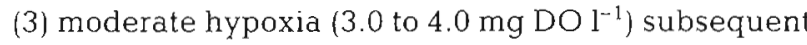
to $24 \mathrm{~h}$ clam acclimation at low oxygen conditions

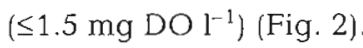

Clams were buried approximately $10 \mathrm{~cm}$ below the sediment surface, and allowed $24 \mathrm{~h}$ to acclimate under high or low oxygen conditions $(\geq 6.0 \mathrm{mg}$ or $\leq 1.5 \mathrm{mg} \mathrm{DO}^{-1}$, respectivelyl and bury to natural depths. Mya arenaria were also positioned at least $10 \mathrm{~cm}$ from the sides of the tank to avoid edge effects on predation rates (Eggleston et al. 1992). Callinectes sapidus were starved for $48 \mathrm{~h}$ to standardize hunger levels prior to their release into the center of each tank. Six to ten $48 \mathrm{~h}$ trials were conducted for each treatment. Prey mortality was quantified by counting surviving clams and umbones of eaten clams.

Consumption (no. of clams eaten per $48 \mathrm{~h}$ ) and proportional mortality rates (no. of clams eaten per clam density per $48 \mathrm{~h}$ ) of Mya arenaria by either 1 or 2 blue crabs were analyzed with separate 2 -way, fixed-factor ANOVA models using clam density and dissolved oxygen concentration as factors. Predator density (1 vs 2 crabs $\operatorname{tank}^{-1}$ ) was not incorporated as a factor in these analyses since the feeding experiments with different 
predator densities were not conducted simultaneously (considered separate experiments; sensu Hurlbert 1984). Qualitative comparisons between the functional responses exhibited by 1 versus 2 blue crabs, however, may suggest behavioral mechanisms leading to the local persistence or extinction of prey populations exposed to different predator densities and varying dissolved oxygen concentrations. Mean consumption and proportional mortality of clams across 2 levels of prey density and 3 levels of dissolved oxygen treat-

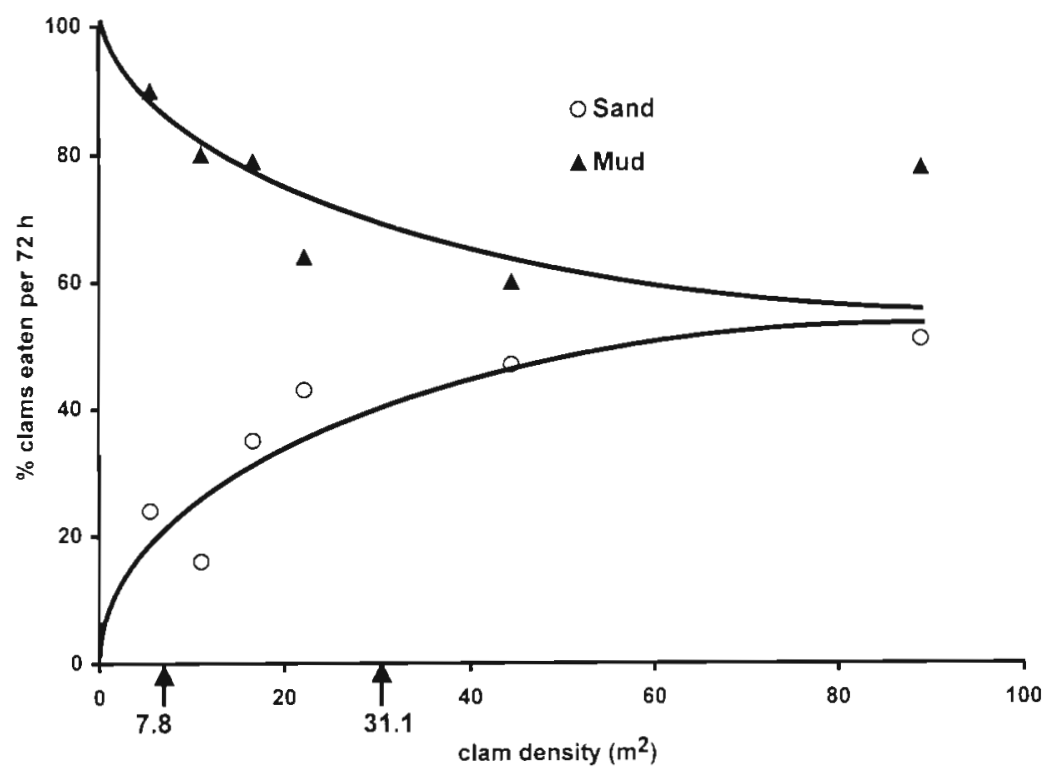

Fig. 1. Proportional mortality rates of Mya arenaria clams to blue crab predation as a function of clam density and sediment type (after Lipcius \& Hines 1986). This figure is used to justify the choice of the 'low range' of experimental prey densities so that differences between functional responses can be distinguished with only 2 data points. Clam densities ( $X$-axis) used in Lipcius \& Hines (1986) were standardized to no. of clams $\mathrm{m}^{-2}$. The experimental clam densities chosen for this study (denoted by the solid black arrows) encompassed low to moderate prey densities and therefore permit efficient statistical differentiation among functional responses based on 2 data points

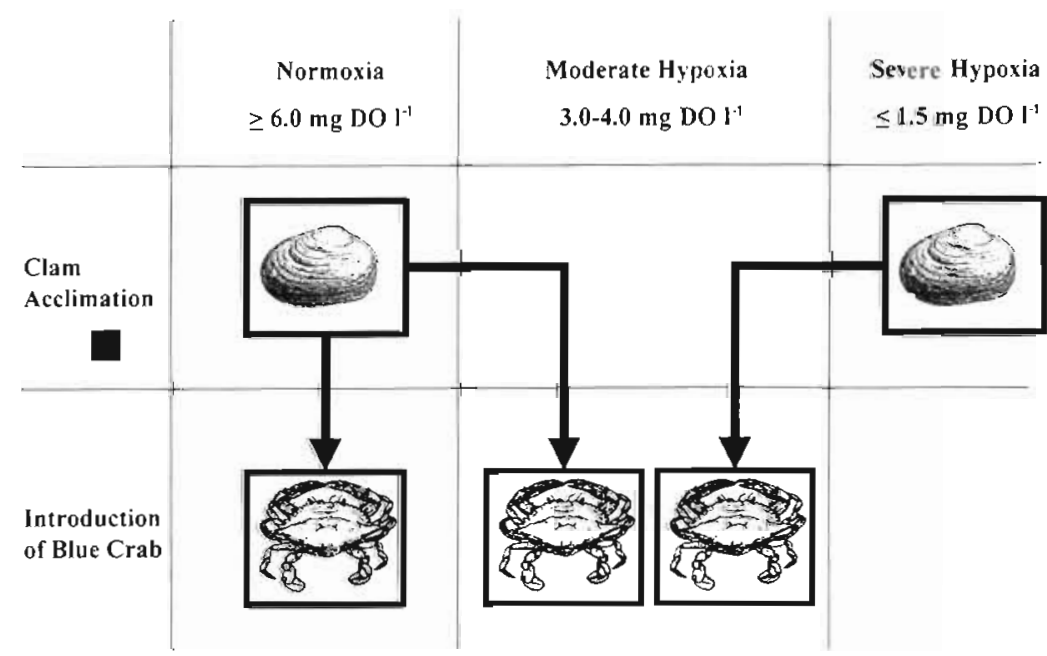

Fig. 2. Schematic of the predator-prey experimental design, which simulates 2 densities of Mya arenaria ( 6 and 24 clams tank ${ }^{-1}$ )

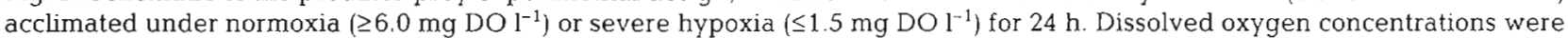
then maintained or raised to either normoxia $\left(\geq 6.0 \mathrm{mg} \mathrm{DO}^{-1}\right)$ or moderate hypoxia $\left(3.0\right.$ to $\left.4.0 \mathrm{mg} \mathrm{DO} \mathrm{l}^{-1}\right)$, respectively, after which 1 or 2 blue crabs were introduced into the experimental arena. Following a $48 \mathrm{~h}$ predation period, counts of surviving $M$. arenaria and umbones of eaten clams were used to calculate consumption rates (no. of clams eaten per $48 \mathrm{~h}$ ) and proportional mortality rates (no. of clams eaten per clam density per $48 \mathrm{~h}$ ). The experimental design simulates drastic fluctuations in dissolved oxygen concentrations characteristic of numerous estuarine systems during summer months 
ments were contrasted with a 2-way ANOVA model and Ryan-Einot-Gabriel-Welsch (Ryan's Q) multiple comparison tests, respectively. A Ryan's $Q$ multiple comparison test was used in cases with unequal sample sizes (i.e. predator-prey experiments), as opposed to the Tukey's multiple comparison test, which was used in situations with equal sample sizes (as recommended by Day \& Quinn 1989).

Efiects of agonism on blue crab functional responses. The effect of physical injury, resulting from intraspecific aggression, on rates of predation by Callinectes sapidus was determined a posteriori by categorizing the 2 -predator, moderate hypoxic oxygen treatment (clams acclimated under severe hypoxia; Fig. 2) as either lacking or demonstrating visible evidence of crab mortality, carapace wounds, or loss of appendages. This 'physical evidence of crab agonism' treatment (present, absent) was chosen a posteriori because there was clear evidence of injury or lack thereof in $50 \%$ of the trials. Consumption and proportional mortality rates were each analyzed with a 2-way, fixed-factor ANOVA model using clam density (low, high) and evidence of crab agonism (present, absent) as factors

\section{RESULTS}

\section{Effects of hypoxia on clam behavior}

As dissolved oxygen concentrations decreased, Mya arenaria migrated toward the sediment surface and extended their siphons above the substrate-seawater interface. Clam burial depths differed significantly according to dissolved oxygen levels (1-way ANOVA: $F=17.18$, df $=2,11, \mathrm{p}<0.01$, and were significantly shallower at low dissolved oxygen concentrations than at moderate or high concentrations (Fig. 3a, Tukey's multiple comparison test). To eliminate potential biases in clam burial depth measurements (resulting from differences in size or initial burying of clams), 'changes' in burial depth were calculated by subtracting the burial depth of clams after a specified dissolved oxygen treatment from the depths achieved after the $24 \mathrm{~h}$ acclimation period. A positive change in depth indicates a decrease in burial depth (i.e. movement to sediment surface), whereas negative values denote an increase in burial depth. Changes in the sediment burial depths of $M$. arenaria differed significantly according to dissolved oxygen concentrations (1-way ANOVA: $F=17.76$, df $=2,11, \mathrm{p}<0.01$ ), and were significantly greater at low dissolved oxygen levels (depth change $=+5.04 \mathrm{~cm}$ at $\leq 1.5 \mathrm{mg} \mathrm{DO} \mathrm{l}^{-1}$ ) than at moderate (depth change $=-0.08 \mathrm{~cm}$ at 3.0 to $4.0 \mathrm{mg} \mathrm{DO} \mathrm{l}^{-1}$ ) or high (depth change $=-0.07 \mathrm{~cm}$ at $\geq 6.0 \mathrm{mg} \mathrm{DO}^{-1}$ ) oxygen concentrations (Tukey's multiple comparison test).

Siphon extension into the water column also differed significantly across dissolved oxygen levels (1-way ANOVA: $F=56.67, \mathrm{df}=2,11, \mathrm{p}<0.01$ ), and was significantly greater at low dissolved oxygen concentrations than at moderate or high concentrations (Fig. 3b, Tukey's multiple comparison test). To eliminate potential biases in siphon extension measurements associ-
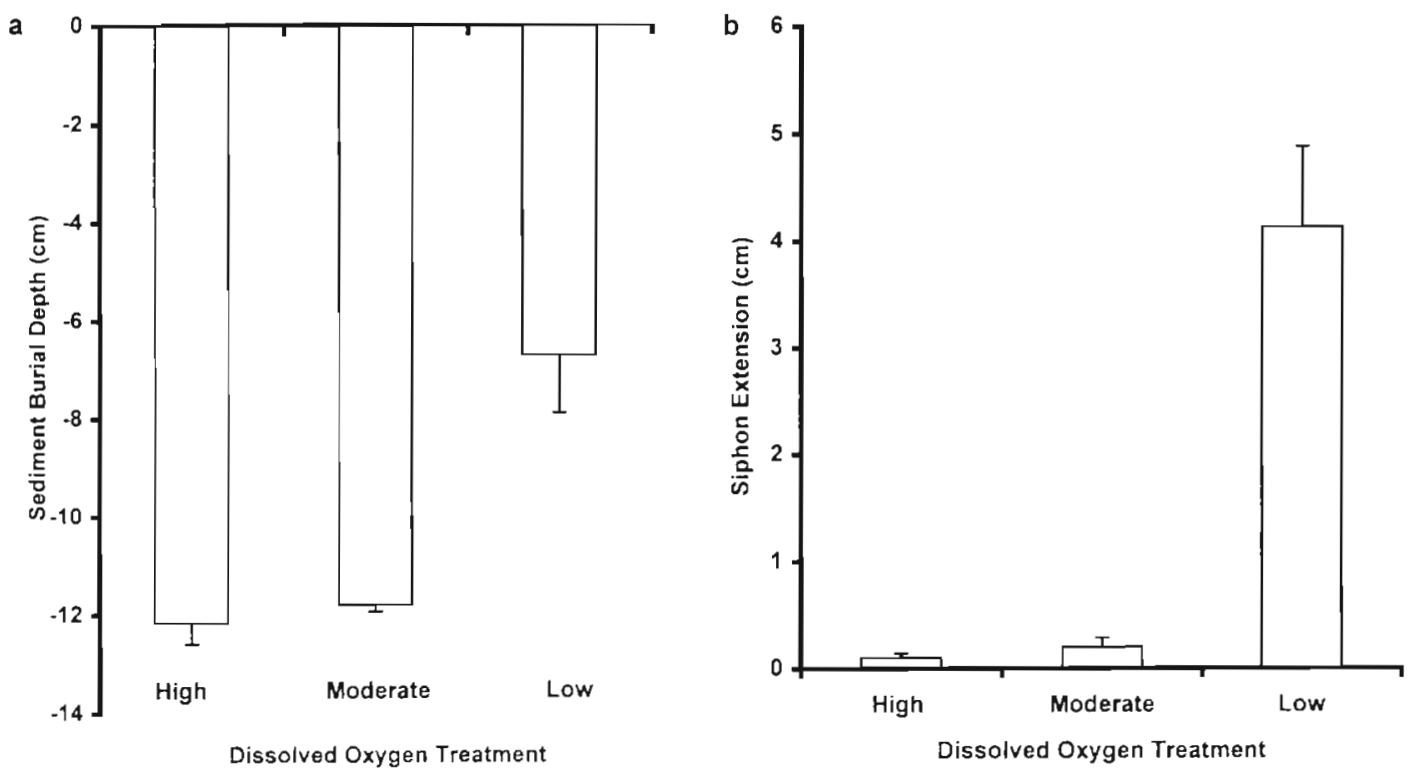

Fig. 3. (a) Sediment burial depth and (b) siphon extension of Mya arenaria in response to a 24 h exposure period to 3 oxygen concentrations: high, moderate, and low (26.0, 3.0 to 4.0, and $\leq 1.5 \mathrm{mg} \mathrm{DO}^{-1}$, respectively). Means (+SE) at each dissolved oxygen treatment are plotted $(n=4)$. See text for significant levels 
ated with clam size, 'changes' in siphon extension were calculated by subtracting the values achieved after a given dissolved oxygen treatment from those recorded after the $24 \mathrm{~h}$ acclimation period. A positive change in siphon extension indicates an increase in extension (i.e. protrusion into the water column), whereas negative values denote a withdrawal in siphon extension. Changes in clam siphon extension differed significantly according to dissolved oxygen levels (1-way ANOVA: $F=99.14$, df $=2,11, \mathrm{p}<0.01$ ), and were significantly greater at low dissolved oxygen levels (extension change $=+3.61 \mathrm{~cm}$ at $\leq 1.5 \mathrm{mg} \mathrm{DO} \mathrm{l}^{-1}$ ) than at moderate (extension change $=-0.05 \mathrm{~cm}$ at 3.0 to $4.0 \mathrm{mg} \mathrm{DO}^{-1}$ ) or high (extension change $=-0.02 \mathrm{~cm}$

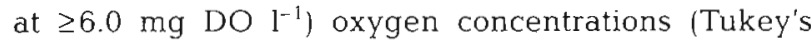
multiple comparison test).

\section{Effects of hypoxia on clam behavior - real time}

The initiation and persistence of severe hypoxia ( $\leq 1.5 \mathrm{mg} \mathrm{DO} \mathrm{l}^{-1}$ ) resulted in the nearly continuous extension of Mya arenaria siphons into the water column (Fig. 4). The behavioral response of clams to hypoxia was immediate; siphon extension occurred at a rate of $0.32 \mathrm{~cm} \mathrm{~h}^{-1}$ over the first $4 \mathrm{~h}$ of exposure to dis- solved oxygen levels less than $1.5 \mathrm{mg} \mathrm{DO} \mathrm{I}^{-1}$ (Fig. 4). The rate of siphon extension gradually decreased with increased exposure time to hypoxia (Fig. 4). Between the fourth and eighth hour of exposure to hypoxia, siphon extension occurred at a rate of $0.13 \mathrm{~cm} \mathrm{~h}^{-1}$ (Fig. 4). Between the eighth and twenty-fourth hour of exposure to hypoxia, siphon extension rates decreased to $0.08 \mathrm{~cm} \mathrm{~h}^{-1}$ (Fig. 4). The return to normoxic conditions $\left(\geq 6.0 \mathrm{mg} \mathrm{DO} \mathrm{l}^{-1}\right.$ ) resulted in siphon withdrawal back into the sediment (Fig. 4). The rate of siphon withdrawal was greatest at the onset of normoxia, and gradually decreased with time $\left(0.44 \mathrm{~cm} \mathrm{~h}^{-1}\right.$ from 0 to 4. $\mathrm{h}_{;} 0.13 \mathrm{~cm} \mathrm{~h}^{-1}$ from 4 to $8 \mathrm{~h}_{i} 0.03 \mathrm{~cm} \mathrm{~h}^{-1}$ from 8 to $24 \mathrm{~h})$.

Mya arenaria burial depth decreased with the initiation and persistence of hypoxia (Fig. 4), and occurred at a rate of $0.17 \mathrm{~cm} \mathrm{~h}^{-1}$. The return to normoxia resulted in a steady rate of sediment reburial of $0.10 \mathrm{~cm} \mathrm{~h}^{-1}$ over the $24 \mathrm{~h}$ period (Fig. 4)

\section{Blue crab satiation levels}

Callinectes sapidus consumed an average of 7.83 Mya arenaria per $48 \mathrm{~h}$ when foraging was unimpeded by sediment. Therefore, the experimental period of

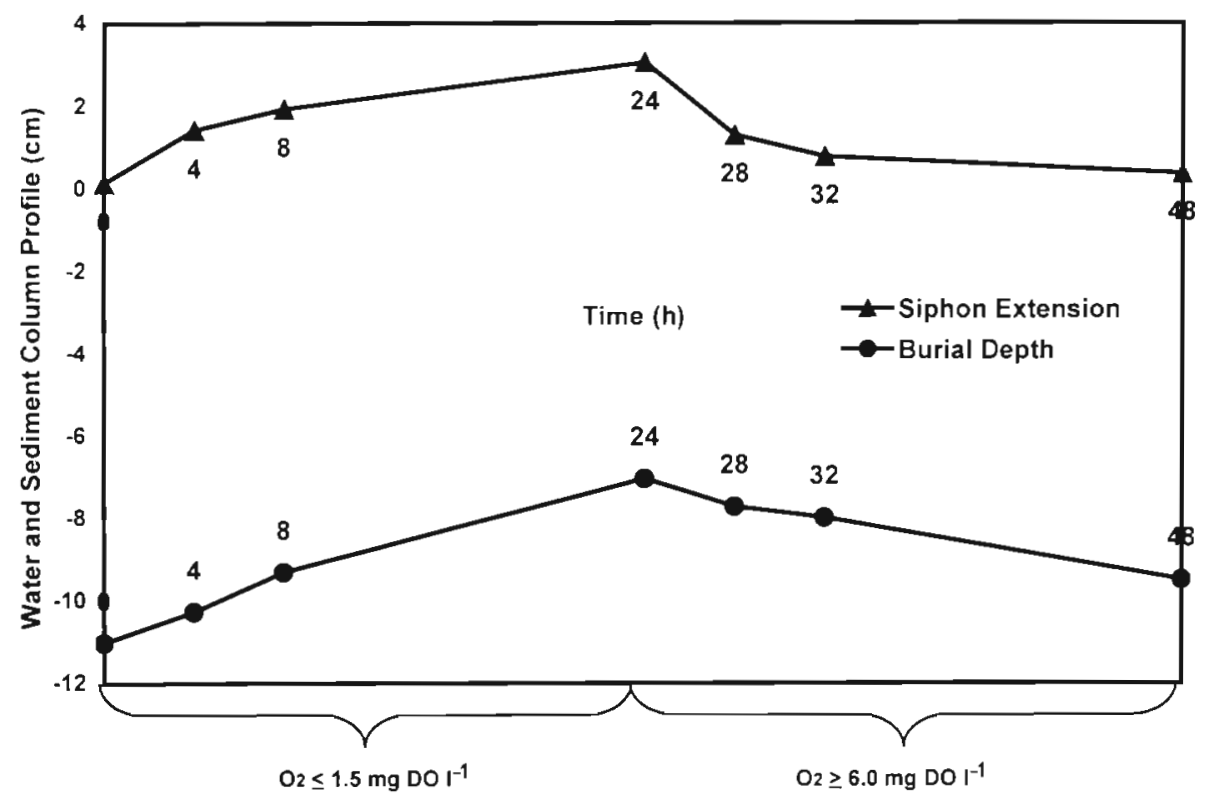

Fig. 4. Rate of change in Mya arenaria burial depth $(\mathrm{cm})$ and siphon extension $(\mathrm{cm})$ in response to fluctuating dissolved oxygen concentrations. Following a $24 \mathrm{~h}$ acclimation period under normoxia, dissolved oxygen levels were lowered to severe hypoxia ( $\leq 1.5 \mathrm{mg} \mathrm{DO}^{-1}$ ) over a $2 \mathrm{~h}$ interval. Dissolved oxygen was maintained at this level for $22 \mathrm{~h}$, after which it was returned to nor-

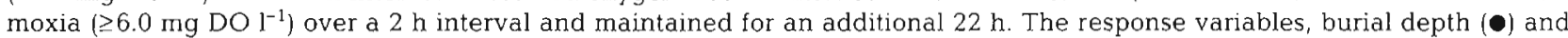
siphon extension $(\mathbf{\Delta})$, were measured 4,8 , and $24 \mathrm{~h}$ after the onset of both the low and high dissolved oxygen treatment $(\leq 1.5$ and $\geq 6.0 \mathrm{mg} \mathrm{DO}^{-1}$, respectively). Experimental dissolved oxygen concentrations (intensity, rate of change, and duration) simulated field data collected by the US Geological Survey, North Carolina District, from the bottom waters of the Neuse River, North Carolina, USA (latitude $34^{\circ} 56^{\prime} 56^{\prime \prime}$, longitude 76 48' 36") during mid-August 1998 
$48 \mathrm{~h}$ and densities of $M$. arenaria used in predator-prey experiments ( 6 and 24 clams tank ${ }^{-1}$ ) did not bias the results against differentiating clam consumption and proportional mortality rates across high and low prey density treatments, since crabs were presumably below satiation.

\section{Effects of hypoxia and mutual interference on predator-prey dynamics}

\author{
Single predator - effects of hypoxia on crab \\ foraging behavior
}

Consumption rates of individual blue crabs differed significantly according to dissolved oxygen concentration and Mya arenaria density (2-way ANOVA; dissolved oxygen treatment: $F=11.36, \mathrm{df}=2,44, \mathrm{p}<0.01$; clam density: $F=6.84, \mathrm{df}=1,44, \mathrm{p}=0.01)$; the interaction effect was not significant $(F=2.51$, df $=2,44, \mathrm{p}=$ 0.09) (Fig. 5a). Consumption rates were significantly higher during normoxia ( $\geq 6.0 \mathrm{mg} \mathrm{DO}^{-1}$ ) and moder-

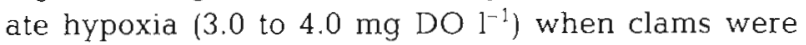
acclimated to severe hypoxia $\left(\leq 1.5 \mathrm{mg} \mathrm{DO}^{-1}\right)$, than during moderate hypoxia when clams were acclimated to normoxia (Fig. 5a, Ryan's $Q$ multiple comparison test). In addition, significantly more $M$. arenaria were consumed at the high clam density (24 clams tank ${ }^{-1}$ ) than the low density ( 6 clams tank ${ }^{-1}$ ) (Fig. 5a, lowerlevel ANOVA).

The proportion of Mya arenaria consumed by a single blue crab also differed significantly by dissolved oxygen concentration and clam density (2-way ANOVA; dissolved oxygen treatment: $F=29.92$, df $=2$, 44, $\mathrm{p}<0.01$; clam density: $F=53.26$, df $=1,44, \mathrm{p}<$ $0.01)$; however, the interaction effect was also significant (2-way ANOVA, $F=18.46$, df $=2,44, p<0.01$ ) (Fig. 5b), precluding contrasts across the main effects. The interaction effect was due to significantly higher proportional mortality rates of $M$. arenaria at low versus high experimental clam densities in normoxia and moderate hypoxia (low dissolved oxygen acclimation for clams) (indicative of a type II functional response); and no difference in proportional mortality rates between clam densities (indicative of a type I functional response) in moderate hypoxia (high dissolved oxygen acclimation for clams) (Fig. 5b, lower-level ANOVA). Thus, during the transition from normoxia to hypoxia, crab foraging behavior was altered drastically such that it was no longer destabilizing to predatorprey dynamics at low prey densities (Fig. 5b). Conversely, as dissolved oxygen concentrations for acclimating clams increased from severe hypoxia $(\leq 1.5 \mathrm{mg}$ $\mathrm{DO}^{-1}$ ) to moderate hypoxia (3.0 to $4.0 \mathrm{mg} \mathrm{DO}^{-1}$ ), crab foraging behavior changed from a type I functional response to a type II functional response; stressed clams with increased siphon extension resided closer to the sediment-water interface and suffered disproportionately high predation-induced mortality at low prey densities (Fig. 5b).

\section{Two predators - effects of hypoxia and mutual interference on crab foraging behavior}

Total consumption rates by 2 Callinectes sapidus differed significantly according to dissolved oxygen concentration and Mya arenaria density (2-way ANOVA; dissolved oxygen treatment: $F=8.05, \mathrm{df}=2,39, \mathrm{p}<$ 0.01; clam density: $F=17.66$, $\mathrm{df}=1,39, \mathrm{p}<0.01$ ); however, the interaction effect was also significant ( $F=$ 9.69, $\mathrm{df}=2,44, \mathrm{p}<0.01$ ) (Fig. $5 \mathrm{c}$ ), precluding contrasts across the main effects. The interaction effect was due to significantly higher clam mortality at high than low clam densities under moderate hypoxia $(3.0$ to $4.0 \mathrm{mg}$ DO $\mathrm{I}^{-1}$ ), when clams were acclimated to severe hypoxia ( $\leq 1.5 \mathrm{mg} \mathrm{DO}^{-1}$ ), and no significant difference in clam mortality rates between clam densities for the remaining dissolved oxygen treatments (Fig. 5c, lowerlevel ANOVA)

Proportional mortality of Mya arenaria also differed significantly by dissolved oxygen concentrations and clam density (2-way ANOVA; dissolved oxygen treatment: $F=8.08, \mathrm{df}=2,39, \mathrm{p}<0.01$; clam density: $F=$ $5.67, \mathrm{df}=1,39, \mathrm{p}=0.02$ ); however, the interaction effect was also significant (2-way ANOVA, $F=9.34$, $\mathrm{df}=2,39, \mathrm{p}<0.01$ ) (Fig. 5d), precluding contrasts across the main effects. The interaction effect was due to significantly higher proportional mortality rates of clams at low versus high clam densities under moderate hypoxia, when clams were acclimated to normoxia (indicative of a type II functional response), and no difference in proportional mortality rates (indicative of a type I functional response) between clam densities under normoxia, or moderate hypoxia when clams were acclimated to severe hypoxia (Fig. 5d, lowerlevel ANOVA).

Mutual interference between 2 large Callinectes sapidus altered the functional response of crabs across all dissolved oxygen treatments (Fig. 5). For example, under normoxia, a single blue crab exhibited a type II functional response to Mya arenaria, whereas 2 crabs exhibited a type I functional response (Fig. 5). Similarly, although a single crab exhibited a type II functional response to $M$. arenaria under moderate hypoxia when clams were acclimated to severe hypoxia, 2 crabs exhibited a type I functional response (Fig. 5). Lastly, under moderate hypoxia, a single blue crab exhibited a type I functional response to $M$. arenaria when clarns had been acclimated to normoxia, whereas 
a

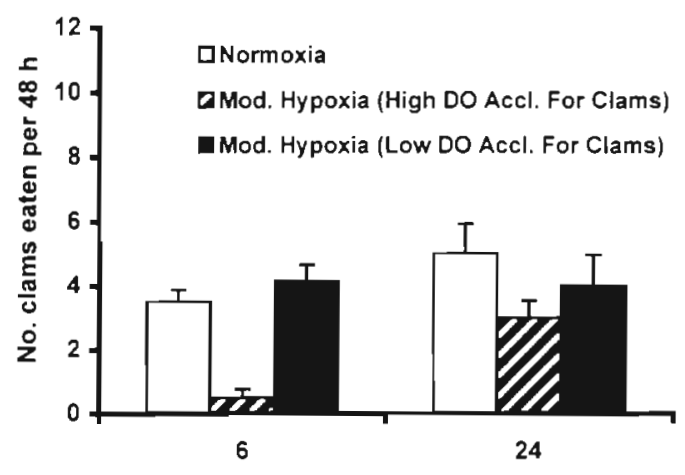

C

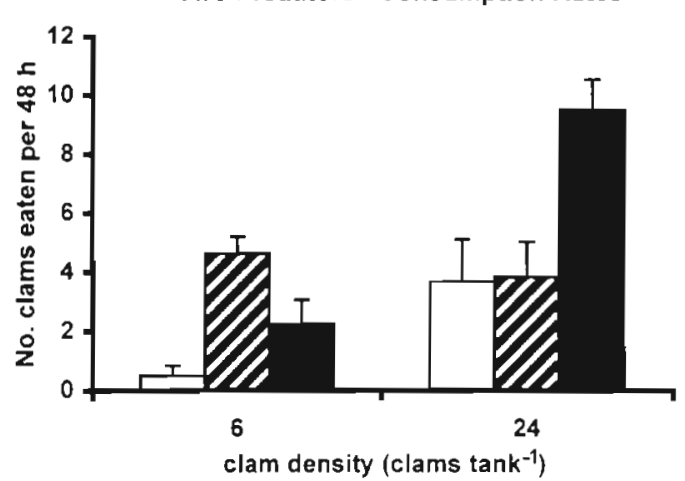

b One Predator - Proportional Mortality Rates
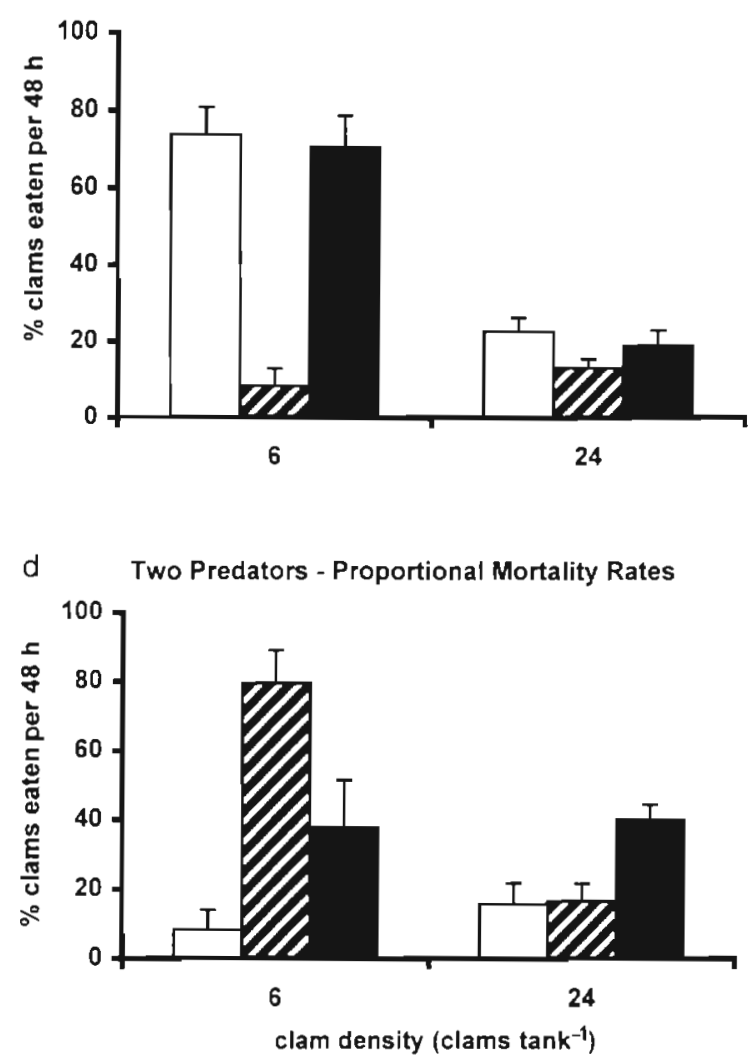

Fig. 5. Summary of (a) consumption rates (no. of clams eaten per $48 \mathrm{~h}$ ) and (b) proportional mortality rates (no. of clams eaten per clam density per $48 \mathrm{~h}$ ) of Mya arenaria by a single Callinectes sapidus, and (c) consumption rates (no. clams eaten per $48 \mathrm{~h}$ ) and (d) proportional mortality rates (no. of clams eaten per clam density per $48 \mathrm{~h}$ ) of $\mathrm{M}$. arenaria by 2 C. sapidus across 2 clam densities ( 6 and 24 clams tank $^{-1}$ ) and 3 dissolved oxygen treatments: normoxia ( $\geq 6.0 \mathrm{mg} \mathrm{DO} \mathrm{l}^{-1}$ ): moderate hypoxia (3.0 to $4.0 \mathrm{mg}$ DO $\left.\mathrm{l}^{-1}\right)$, with clams acclimated to high oxygen conditions $\left(\geq 6.0 \mathrm{mg} \mathrm{DO} \mathrm{l^{-1 }}\right)$; and moderate hypoxia $\left(3.0\right.$ to $\left.4.0 \mathrm{mg} \mathrm{DO}^{-1}\right)$, with clams

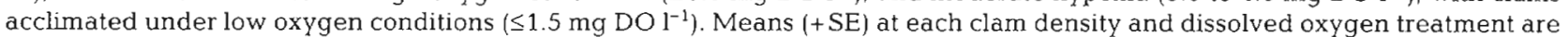
plotted. See text for significant levels

2 crabs exhibited a type II functional response under such conditions (Fig. 5).

\section{Effects of agonism on blue crab functional responses}

Physical evidence of agonism between Callinectes sapidus in the experiments with 2 predators significantly affected proportional mortality rates of Mya arenaria, altering the functional response of blue crabs (Fig. 6). Total consumption rates of 2 C. sapidus differed significantly according to whether or not physical evidence of blue crab agonism was present, as well as $M$. arenaria density (2-way ANOVA; agonism: $F=$ 10.33, df $=1,13, \mathrm{p}<0.01$; clam density: $F=50.00$, df $=$ $1,13, p<0.01)$; the interaction effect was not significant ( $F=0.81$, df $=1,13, p=0.38$ ) (Fig. 6a). Consumption rates of $M$. arenaria by $C$. sapidus bearing evidence of physical injury were significantly lower than for undamaged blue crabs (Fig. 6a, lower-level ANOVA). In addition, significantly more $M$. arenaria were consumed at the high versus low clam density (Fig. 6a, lower-level ANOVA).

The proportion of clams consumed also differed significantly according to whether or not there was physical evidence of blue crab agonism, but not by $M y a$ arenaria density (2-way ANOVA; agonism: $F=22.89$, df $=1,13, \mathrm{p}<0.01$; clam density: $F=0.00, \mathrm{df}=1,13$, $\mathrm{p}=0.95)$; however, the interaction effect was also significant $(F=12.23$, df $=1,13, \mathrm{p}<0.01)$ (Fig. 6b), precluding contrasts across main effects. Foraging by intact (undamaged) blue crabs demonstrated a type II functional response, as clams suffered significantly greater proportional mortality at low versus high prey densities (Fig. 6b, lower-level ANOVA). M. arenaria suffered greater proportional mortality at high versus low clam densities when preyed upon by injured Callinectes sapidus, indicating that blue crabs exhibit a type III functional response under conditions that 
a

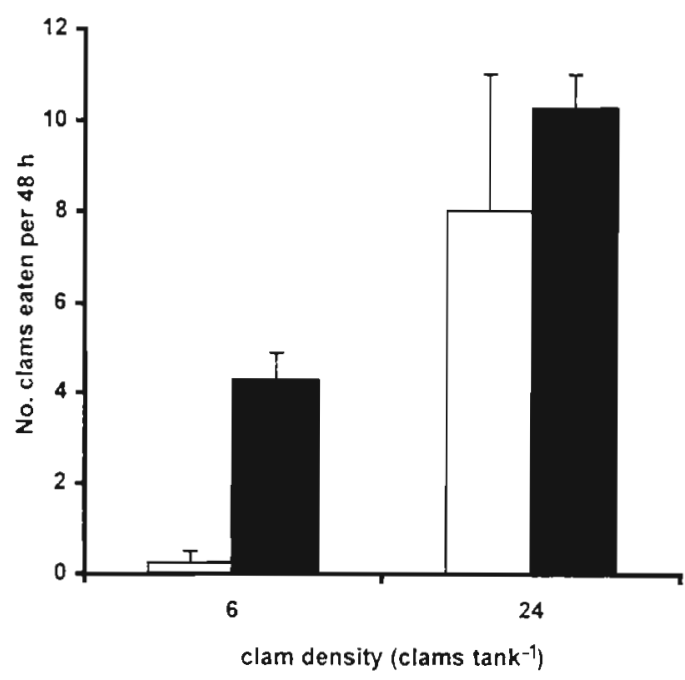

b Effects of Agonism on Proportional Mortality

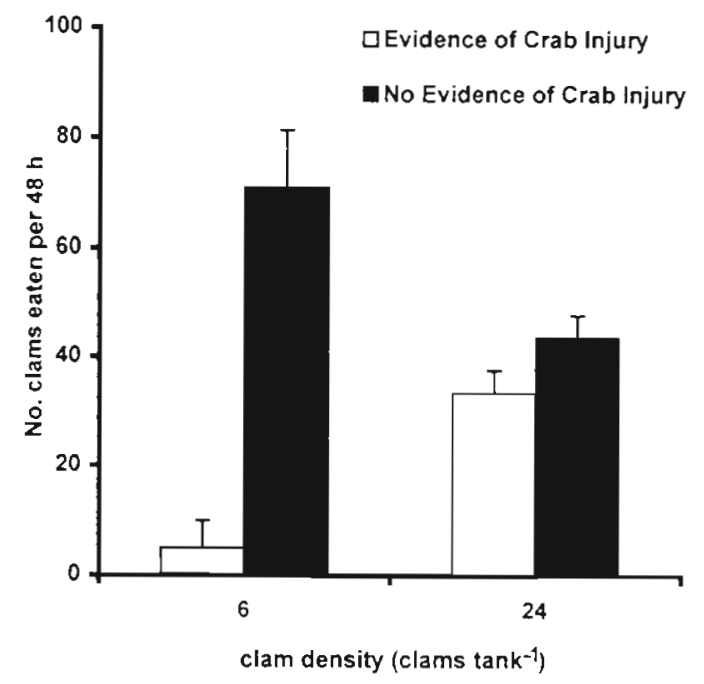

Fig. 6. Effects of Callinectes sapidus agonism (present and absent) and Mya arenaria density $\left\{6\right.$ and $24 \mathrm{clams} \operatorname{tank} \mathrm{k}^{-1}$ ) on (a) consumption rates (no. of clams eaten per $48 \mathrm{~h}$ ) and (b) proportional mortality rates (no. of clams eaten per clam density per $48 \mathrm{~h}$ ) of

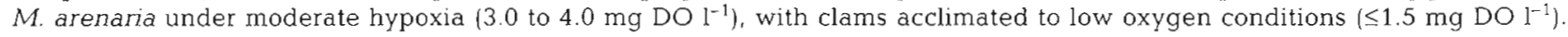
Means (+SE) at each clam density and dissolved oxygen treatment are plotted. See text for significant levels

result in agonism and physical damage (Fig. 6b, lowerlevel ANOVAl

\section{DISCUSSION}

Results from this study provide quantitative insight regarding the impact of fluctuations in dissolved oxygen levels on prey refuges for infaunal clam populations, as well as predator-prey dynamics between Callinectes sapidus and clam prey. Mya arenaria obtained a partial prey refuge from blue crab predation when dissolved oxygen concentrations decreased from normoxia to moderate hypoxia ( $\geq 6.0 \mathrm{mg}$ to $3.0-4.0 \mathrm{mg}$ DO $\mathrm{l}^{-1}$ ), where the foraging behavior of blue crabs upon clam prey changed from a destabilizing, type II functional response, to a partially stabilizing, type I functional response (Table 1 ). $M$. arenaria's low density prey refuge at moderate hypoxia was lost, however, when blue crabs preyed upon clams that were previously acclimated under severe hypoxia $(\leq 1.5 \mathrm{mg}$ DO $\mathrm{l}^{-1}$ ) (indicative of a type II functional response) (Table 1).

The inclusion of a second blue crab predator in experimental trials further modified crab functional responses (Table 1). The initiation of moderate hypoxia from normoxia changed the foraging behavior of 2 blue crabs from a type I functional response to a type Il response (Table 1). Conversely, 2 blue crabs exhibited a type I functional response under moderate hypoxia subsequent to clam exposure to severe hypoxia
(Table 1). The collective results indicate that fluctuations in dissolved oxygen concentrations, as well as both predator and prey density, must be examined jointly to understand their impact upon predator-prey dynamics in marine systems.

The underlying mechanism controlling the effects of hypoxia on the predator-prey dynamics between Callinectes sapidus and Mya arenaria is the behavioral response of clam prey to low oxygen conditions; i.e prey behavioral responses that affect burial depth and siphon extension altering $M$. arenaria's vulnerability to blue crab predation. In this study, very low dissolved oxygen concentrations ( $\leq 1.5 \mathrm{mg} \mathrm{DO} \mathrm{l}^{-1}$ ) significantly decreased the burial depth of $M$. arenaria, rendering clams more accessible to foraging blue crabs. The morphological characteristics (i.e. spines, varices, thickness of shells) of many molluscan prey species serve as a deterrent to predation (Vermeij 1978, Palmer 1979, Blundon \& Kennedy 1982a). For example, large juvenile oysters Crassostrea virginica are able to attain an absolute prey refuge from foraging female blue crabs in conjunction with increases in size and shell thickness (Eggleston 1990b). Conversely, mature $M$. arenaria possess a relatively thin shell with a siphonal and pedal gape, lacking any prominent predator-resistant morphological features (Boulding 1984). Structural analyses of $M$. arenaria detected that their shells were never strong enough to confer resistance to crushing by blue crabs (i.e. provided no size refuge) (Blundon \& Kennedy 1982a). The absence of anti-predator shell features in $M$. arenaria reflects the partial refuge pro- 
Table 1 Results of Callinectes sapidus-Mya arenaria predator-prey experiments with 1 and 2 predators, demonstrating consumption rates (no. of clams eaten per $48 \mathrm{~h}$ ) and proportional mortality rates (no. of clams eaten per clam density per $48 \mathrm{~h}$ ) for

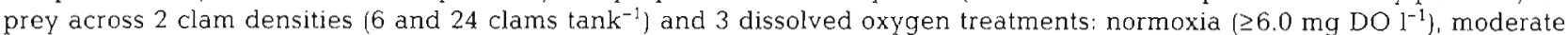
hypoxia ( 3.0 to $4.0 \mathrm{mg} \mathrm{DO}^{-1}$ ), with clams acclimated under high oxygen conditions $\left(\geq 6.0 \mathrm{mg} \mathrm{DO}{ }^{-1}\right)$; and moderate hypoxia $(3.0$ to $4.0 \mathrm{mg} \mathrm{DO} \mathrm{^{-1 }}$ ), with clams acclimated under low oxygen conditions ( $\leq 1.5 \mathrm{mg} \mathrm{DO}^{-1}$ ). The effect of blue crab agonism on consumption and proportional mortality rates for clams is reported for the moderate hypoxic $\left(3.0\right.$ to $\left.4.0 \mathrm{mg} \mathrm{DO}^{-1}\right)$ treatment in which clams were acclimated under severe hypoxia $\left(\leq 1.5 \mathrm{mg} \mathrm{DO}^{-1}\right)$. The number of replicates $(\mathrm{n})$ per treatment combination, the type of functional response under different experimental treatments, and the hypothesized behavioral mechanisms underlying variable functional responses are summarized

\begin{tabular}{|c|c|c|c|c|}
\hline $\begin{array}{l}\text { Dissolved oxgen } \\
\text { treatment }\end{array}$ & $\mathrm{n}$ & $\begin{array}{c}\text { Clam } \\
\text { density }\end{array}$ & $\begin{array}{l}\text { Functional } \\
\text { response }\end{array}$ & $\begin{array}{l}\text { Hypothesized } \\
\text { behavioral mechanism }\end{array}$ \\
\hline \multicolumn{5}{|l|}{ One crab } \\
\hline Normoxia & $\begin{array}{l}8 \\
6\end{array}$ & $\begin{array}{r}6 \\
24\end{array}$ & Type II & $\begin{array}{l}\text { Relatively high encounter rates by crabs } \\
\text { with clam siphons in mud }\end{array}$ \\
\hline $\begin{array}{l}\text { Moderate hypoxia } \\
\text { (high DO accl. for clams) }\end{array}$ & $\begin{array}{r}10 \\
7\end{array}$ & $\begin{array}{r}6 \\
24\end{array}$ & Type I & $\begin{array}{l}\text { Decreased activity of blue crabs with } \\
\text { exposure to low dissolved oxygen }\end{array}$ \\
\hline $\begin{array}{l}\text { Moderate hypoxia } \\
\text { (low DO accl. for clams) }\end{array}$ & $\begin{array}{l}7 \\
7\end{array}$ & $\begin{array}{r}6 \\
24\end{array}$ & Type II & $\begin{array}{l}\text { Increased clam vulnerability due to } \\
\text { shallow burial depth and increased } \\
\text { siphon extension }\end{array}$ \\
\hline \multicolumn{5}{|l|}{ Two crabs } \\
\hline Normoxia & $\begin{array}{l}6 \\
6\end{array}$ & $\begin{array}{r}6 \\
24\end{array}$ & Type I & $\begin{array}{l}\text { Mutual interference between crabs } \\
\text { at low prey densities reduces predator } \\
\text { foraging efficiency }\end{array}$ \\
\hline $\begin{array}{l}\text { Moderate hypoxia } \\
\text { (high DO accl. for clams) }\end{array}$ & $\begin{array}{l}8 \\
6\end{array}$ & $\begin{array}{r}6 \\
24\end{array}$ & Type II & $\begin{array}{l}\text { Mutual attacks of crabs on prey enhances } \\
\text { predator foraging efficiency }\end{array}$ \\
\hline $\begin{array}{l}\text { Moderate hypoxia } \\
\text { (low DO accl. for clams) }\end{array}$ & $\begin{array}{l}8 \\
6\end{array}$ & $\begin{array}{r}6 \\
24\end{array}$ & Type I & $\begin{array}{l}\text { Mutual interference between crabs } \\
\text { at low prey densities reduces predator } \\
\text { foraging efficiency }\end{array}$ \\
\hline \multicolumn{5}{|l|}{ Agonism absent } \\
\hline $\begin{array}{l}\text { Moderate hypoxia } \\
\text { (low DO accl. for clams) }\end{array}$ & $\begin{array}{l}4 \\
6\end{array}$ & $\begin{array}{r}6 \\
24\end{array}$ & Type II & $\begin{array}{l}\text { Mutual attacks of crabs on prey enhances } \\
\text { predator foraging efficiency }\end{array}$ \\
\hline \multicolumn{5}{|l|}{ Agonism present } \\
\hline $\begin{array}{l}\text { Moderate hypoxia } \\
\text { (low DO accl. for clams) }\end{array}$ & $\begin{array}{l}4 \\
6\end{array}$ & $\begin{array}{r}6 \\
24\end{array}$ & Type III & $\begin{array}{l}\text { Mutual interference between crabs } \\
\text { at low prey densities reduces predator } \\
\text { foraging efficiency }\end{array}$ \\
\hline
\end{tabular}

vided by their infaunal existence (Boulding 1984). Although predators such as blue crabs are capable of excavating moderately deep clams (ca $10 \mathrm{~cm}$; Blundon \& Kennedy 1982a), crabs forage more efficiently near the sediment surface (Blundon \& Kennedy 1982b, Boulding 1984). Previous studies examining the effectiveness of possible refuges within the sediment in protecting $M$. arenaria from blue crab predation determined that crabs foraged less efficiently on clams residing deeper than $10 \mathrm{~cm}$ in the sediment column than on those closer to the surface (Blundon \& Kennedy 1982b). Thus, factors eliminating the deep burial depths of $M$. arenaria appear detrimental to clam survival.

When blue crabs foraged upon Mya arenaria under

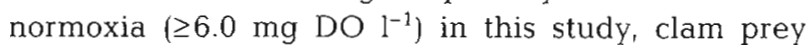
suffered a higher risk of mortality at low versus high densities (indicative of a type II functional response) (Table 1). Thus, the observed pattern of inversely density-dependent mortality of clam prey under high oxygen conditions was consistent with the findings of Lip- cius \& Hines (1986). Accordingly, $M$. arenaria were incapable of attaining a low density, deep burial depth refuge from blue crab predation in muddy substrates The absence of a low-density refuge for clams in mud was attributed to the increased penetration of the tips of the walking legs of blue crabs in mud versus sand sediments (Lipcius \& Hines 1986) (Table 1). Furthermore, the physical attributes of mud may facilitate the excavation of $M$. arenaria because sand tends to refill holes faster during blue crab digging than in mud (pers. obs.) (Table 1).

The initiation of moderate hypoxia following normoxic conditions dramatically modified the functional response of Callinectes sapidus from a type II functional response to a type I response (Table 1). Mya arenaria attained a partial refuge at this lower oxygen level due to different tolerance levels of predatory blue crabs and their clam prey to hypoxia (Table 1). Blue crabs are highly sensitive to low oxygen conditions (Pihl et al. 1991, Das \& Stickle 1993, 1994, Diaz 
\& Rosenberg 1995), decreasing their activity and becoming quiescent when exposed to even moderate hypoxia (pers, obs.). Conversely, burial depth and siphon extension of $M$. arenaria appeared unaffected by moderate hypoxia. Under lower oxygen concentrations, stressed blue crabs do not expend the energy required to excavate deeply buried clam prey. Moreover, in natural populations the mobility and resulting horizontal or vertical migration of $C$. sapidus away from hypoxic waters ( 3.0 to $4.0 \mathrm{mg} \mathrm{DO}^{-1}$ ) allow blue crabs to avoid the deleterious effects associated with severe oxygen limitation (Pihl et al. 1991, Nestlerode \& Diaz 1998). Consequently, crab emigration under hypoxic conditions indirectly establishes a prey refuge for $M$. arenaria at oxygen concentrations below moderate hypoxia as clams benefit from the temporary absence of one of their key predators. Thus, $M$. arenaria indirectly utilizes hypoxic regimes as a refuge from blue crab predation through the maintenance of deep burial depths, and relative inactivity or absence of crabs.

Mya arenaria exposed to severe hypoxia $(\leq 1.5 \mathrm{mg}$ DO $\mathrm{l}^{-1}$ ) decreased their sediment burial depth and increased their siphon extension. The rapid dissipation of low oxygen episodes in the field may allow blue crabs to return to affected areas and take predatory advantage of easily accessible clams. Under moderate hypoxia, blue crabs foraging upon clams previously acclimated under severe hypoxia exhibited a type II functional response (Table 1). The low-density prey refuge, previously achieved at moderate hypoxia when clams were acclimated under normoxia, was lost when oxygen concentrations recovered from severe hypoxia (as opposed to decreasing from normoxia) (Table 1). The decrease in clam burial depth under severe hypoxia probably facilitated excavation by blue crabs and subsequent predation (Table 1). Additionally, while increases in siphon extension did not evoke a high incidence of sub-lethal predation (siphon cropping), it is probable that prey encounter rates by foraging blue crabs were enhanced as a function of increased visual and tactile detection of protruding clam siphons (Table 1).

The inclusion of a second Callinectes sapidus predator altered the functional response of blue crabs through the initiation of mutual interference and intraspecific agonism (Table 1). Under normoxia, blue crabs exhibited a type I functional response to varying densities of clam prey (Table 1). The underlying mechanism shifting the foraging behavior of solitary blue crabs from a type II functional response to a type I response for 2 crabs was attributed to a higher incidence of agonism in 2 predator treatments at low versus high prey densities (Table 1). The observed patterns of reduced foraging efficiency due to predator agonism were consistent with a previous study of the impact of mutual interference on blue crab predation upon the soft-shelled clam Macoma balthica, where agonistic interactions between blue crabs stabilized predator-prey dynamics at low clam densities (Mansour \& Lipcius 1991). In this study, qualitative comparisons of consumption and proportional mortality rates of Mya arenaria across the 2 densities of $C$. sapidus ( 1 and 2 crabs $\operatorname{tank}^{-1}$ ) suggest that interference responses by blue crabs at high predator densities significantly decrease the magnitude of predation intensity upon clam prey. First, mutual interference between predatory blue crabs potentially decreases crab searching, foraging, and prey handling efficiency. Mansour \& Lipcius's (1991) study of mutual interference among blue crabs foraging upon $M$. balthica confirmed that increasing predator density resulted in a higher incidence of agonistic interactions, which subsequently decreased foraging efficiency of blue crabs upon infaunal clam prey. Second, the occurrence of cannibalism in 2 predator experiments may reduce the need to forage for clam prey as the consumption of conspecifics by blue crabs becomes an additional or alternative food resource. Previous field (Laughlin 1982) and laboratory (Mansour \& Lipcius 1991) studies indicate that cannibalism is common in C. sapidus. Hence, consumption of conspecifics constitutes a major component of the diet of blue crabs, particularly in the late summer-early fall when the abundance of infaunal clam prey has dramatically declined (Fox 1975, Mansour 1992). Third, agonistic interactions resulting in the loss of blue crab appendages potentially hinder the excavation of $M$. arenaria. In a laboratory study that examined the effects of appendage loss on rates at which injured blue crabs forage on $M$. arenaria, Smith \& Hines (1991) determined that crabs missing both chelipeds experience significantly lower consumption rates upon buried clams as compared to blue crabs whose chelipeds remained intact.

The joint foraging rate of 2 Callinectes sapidus was enhanced when dissolved oxygen levels decreased from normoxia to moderate hypoxia (Table 1). Thus, under moderate hypoxia, foraging by 2 predators on infaunal clam prey appears more successful than individual crab foraging responses. A similar response was detected in a field investigation that examined direct and indirect interactions between predatory blue crabs and the demersal fish, spot Leiostomus xanthurus, and their benthic prey (Martin et al. 1989). The foraging efficiency of spot was enhanced by the presence of additional blue crab predators, as crabs made copepods and amphipods more accessible to spot predation by grazing their algal prey refuge, Enteromorpha intestinalis (Martin et al. 1989). The behavior of one predator that minimizes the structural complexity of a 
habitat can therefore lead to increased inter- and intraspecific predator efficiency (Crowder \& Cooper 1982, Leber 1985, Martin et al. 1989). Similarly, blue crabs exposed to moderate hypoxia may forage upon deeply buried Mya arenaria for only short time intervals before becoming quiescent (Table 1). If these crabs, which may be stressed under hypoxic conditions, only partially excavate clams, the foraging efficiency by additional blue crabs may be enhanced if they feed in the same area on newly accessible prey. The combined foraging rates of 2 blue crab predators would be greater (compared to a single predator) if the net result were crabs unintentionally assisting in the excavation of clam prey (i.e. foraging at different times within the same area) without encountering agonistic interactions between each other (Table 1). A previous study that staged fighting contests between sizematched male shore crabs Carcinus maenas under a range of water oxygen tensions (between 10 and $100 \%$ oxygen saturation), determined that the initiation of hypoxic episodes minimized the frequency and duration of aggressive encounters between crabs (Sneddon et al. 1999). The analyses of physiological responses to fighting between 2 shore crabs suggest that contests staged under hypoxia were significantly shorter, whereby crabs exhibited elevated concentrations of haemolymph metabolites (L-lactate and glucose) in muscle tissue (Sneddon et al. 1999). Decreased fighting episodes between crabs under hypoxia imply that metabolite accumulation may be acting as a physiological constraint that limits crabs to a few minutes of activity under oxygen-stressed conditions (Sneddon et al. 1999).

Mya arenaria recovering from severe hypoxia in this study attained a partial prey refuge from the foraging of 2 blue crab predators when dissolved oxygen concentrations were raised to moderate levels (Table 1). The observed type I functional response in this situation was probably due to mutual interference between Callinectes sapidus, which imparted partial stability to crab-clam predator-prey dynamics at low clam densities (Table 1).

The effect of intraspecific aggression on blue crab foraging behavior in this study was determined by categorizing trials a posteriori according to whether or not there was visible evidence of damage and injury to blue crabs. Damaged blue crabs exhibited a type III functional response, whereas intact crabs demonstrated a type II functional response. These results imply that increased predator density and presumed mutual interference between foraging crabs (Mansour \& Lipcius 1991) do not necessarily account for the stabilizing effect on clam prey populations. Instead, the foraging response of 2 blue crabs preying upon infaunal clams was inhibited only in conjunction with intraspecific confrontations between agonistic crabs that resulted in mortality or physical injury.

The results of this laboratory investigation indicate that the interactive effects of prey and predator density are important factors in determining the local persistence of clams in prey patches. Furthermore, the results suggest that mutual interference between blue crabs affects the magnitude of predation intensity across all dissolved oxygen levels. In field conditions, however, it is unclear whether agonistic interactions lead primarily to avoidance responses and hence predator dispersal, or if predator aggregation persists at vulnerable prey patches despite the occurrence of intraspecific aggression leading to crab injury or mortality (Clark 1997). The distinction between the aggregative and avoidance response in blue crabs is critical in determining predator-prey dynamics and community organization in marine soft-bottom benthic communities (Clark 1997). This study was limited in that confinement within the experimental arena negated the opportunity for blue crabs to disperse in response to agonistic encounters with other blue crab predators. Thus, in situ behavioral studies are required to quantify aggregative and avoidance responses occurring between blue crabs when they are confronted with hypoxic situations.

Drastic fluctuations in dissolved oxygen concentrations have the ability to influence trophic dynamics between predators and their benthic prey. Moreover, trophic interactions under hypoxic conditions have important short-and long-term implications for energy flow within estuarine ecosystems. This study suggests that the initiation of moderate hypoxia from normoxic regimes has an inhibitory effect on individual blue crab foraging efficiency. The increased tolerance of infaunal clam prey to low oxygen conditions allows Mya arenaria to indirectly utilize moderate hypoxic situations as a refuge from blue crab predation through the maintenance of their deep burial depths. Accordingly, there may be decreased energy flow from clams (secondary producers) to upper trophic levels since stressed crabs do not expend the energy required to excavate and consume deeply buried clams

Mya arenaria exposed to severe hypoxia require a recovery period on the order of hours or days to reburrow and resume normal activity (Jørgensen 1980, this study). The ability of blue crabs to avoid severe hypoxic regions, however, eliminates their need for a recovery time from oxygen stress before feeding can commence (Nestlerode \& Diaz 1998). Blue crabs may be able to quickly move into affected areas as soon as oxygen levels are tolerable and take predatory advantage of susceptible $M$. arenaria before clams have time to recover and reburrow in the sediment. The immediate pulse of energy that follows a severe hypoxic 
event, due to enhanced feeding by crabs on shallow dwelling clams, may temporarily benefit blue crab predators, but the long-term implication could leave crabs with reduced food resources later in the season or in following prey generations (Diaz \& Rosenberg 1995, Nestlerode \& Diaz 1998). For example, if significant numbers of prey are removed, either by blue crabs driving $M$. arenaria populations to local extinction (indicative of a type II functional response), or by hypoxia-induced clam mortality, the long-term predation rate and subsequent energy flow from clams to upper trophic levels may be drastically reduced.

Results of studies concentrating on the impact of anthropogenic perturbations on marine and estuarine systems are essential for predicting the effects of changes in water quality on trophic interactions and food web dynamics. This laboratory investigation emphasized the importance of quantifying the main and interactive effects of hypoxia on predator-prey interactions. Because macrobenthic fauna differ in their ability to tolerate and recover from oxygen stress, periods of benthic hypoxia could dramatically influence the structure of marine soft-bottom communities. To fully understand the effect of hypoxia on trophic dynamics, further in situ studies are required to examine the (1) recovery rates of prey species to hypoxia, (2) migratory behavior of mobile predators in response to oxygen-stressed areas, and (3) impact of predator aggregative or avoidance responses to predator-prey dynamics

Acknowledgements. We thank the National Marine Fisheries Service and Duke Marine Laboratory, Beaufort, North Carolina for the allocation of laboratory space and equipment. We are also grateful to J. Rice and T. Wolcott for scientific and editorial reviews which greatly improved this manuscript. Financial support for this project was provided by North Carolina Sea Grant College Program (Grant NA46RG0087), and the National Science Foundation (OCE 97-34472).

\section{LITERATURE CITED}

Abrams P, Hill C, Elmgren R (1990) The functional response of the predatory polychaete, Harmothoe sarsi, to the amphipod, Pontoporeia affinis. Oikos 59:261-269

Baird D, Ulanowicz RE (1989) The seasonal dynamics of the Chesapeake Bay ecosystem. Ecol Monogr 59(4):329-364

Batterton CV, Cameron JN (1978) Characteristics of resting ventilation and response to hypoxia, hypercapnia, and emersion in the blue crab, Callinectes sapidus (Rathbuni. J Exp Zool 203:403-418

Blumberg AF, Goodrich DM (1990) Modeling of windinduced destratification in Chesapeake Bay. Estueries $13: 236-249$

Blundon JA, Kennedy VS (1982a) Mechanical and behavioral aspects of blue crab, Callinectes sapidus (Rathbun), predation on Chesapeake Bay bivalves. J Exp Maí Biol Ecol $65: 47-65$
Blundon JA, Kennedy VS (1982b) Refuges for infaunal bivalves from blue crab Callinectes sapidus predation in Chesapeake Bay. J Exp Mar Biol Ecol 65:67-81

Boulding EG (1984) Crab-resistant features of shells of burrowing bivalves: decreasing vulnerability by increasing handling time. J Exp Mar Biol Ecol 76:201-233

Breitburg DL (1992) Episodic hypoxia in Chesapeake Bay: interacting effects of recruitment behavior, and physical disturbance. Ecol Monogr 62(4):525-546

Breitburg DL, Steinberg N, DuBeau S, Cooksey C, Houde ED (1994) Effects of low dissolved oxygen on predation on estuarine fish larvae. Mar Ecol Prog Ser 104:235-246

Clark ME (1997) Foraging behavior and intraspecific interactions of blue crabs (Callinectes sapidus) in a patchy environment: observation of individuals by ultrasonic telemetry. PhD dissertation, North Carolina State University, Raleigh

Crowder LB, Cooper WE (1982) Habitat structural complexity and the interaction between bluegills and their prey. Ecology 63:1802-1813

Das T, Stickle WB (1993) Sensitivity of crabs Callinectes sapidus and $C$. similis and the gastropod Stramonita haeastoma to hypoxia and anoxia. Mar Ecol Prog Ser 98 $263-274$

Das T. Stickle WB (1994) Detection and avoidance of hypoxic water by juvenile Callinectes sapidus and C. similis. Mar Biol 120:593-600

Day RW, Quinn GP (1989) Comparisons of treatments after an analysis of variance in ecology. Ecol Monogr 59(4) 433-463

DeFur PL, Mangum CP, Reese JE (1990) Respiratory responses of the blue crab Callinectes sapidus to longterm hypoxia. Biol Bull 178:46-54

Desprez M, Rybarcyzk H, Wilson JG, Ducrotoy JP, Sueur F Olivesi R, Elkaim B (1992) Biological impact of eutrophication in the Bay of Somme and the induction and impact of anoxia. Neth J Sea Res 30:149-159

Diaz RJ, Rosenberg R (1995) Marine benthic hypoxia: a review of its ecological effects and behavioral responses of benthic macrofauna. Oceanogr Mar Biol Annu Rev 33 : 245-303

Eggleston DB (1990a) Foraging behavior of the blue crab Callinectes sapidus, on juvenile oysters, Crassostrea virginica: effects of prey density and size. Bull Mar Sci 46:62-82

Eggleston DB (1990b) Behavioural mechanisms underlying variable functional responses of blue crabs, Callinectes sapidus feeding on juvenile oysters, Crassostrea virginica. J Anim Ėcol 59:615-630

Eggleston DB (1990c) Functional responses of blue crabs Callinectes sapidus Rathbur feeding on juvenile oysters Crassostrea virginica (Gmelin): effects of predator sex and size, and prey size. J Exp Mar Biol Ecol 143:73-90

Eggleston DB, Lipcius RN, Hines AH (1992) Density-dependent predation by blue crabs upon infaunal clam species with contrasting distribution and abundance patterns. Mar Ecol Prog Ser 85:55-68

Folk RL (1974) Petrology of sedimentary rocks. Hemphills Publishing Co, Austin

Fox LR (1975) Cannibalism in natural populations. Annu Rev Ecol Syst 6:87-106

Gade G (1983) Energy metabolism of arthropods and mollusks during environmental and functional anaerobiosis. J Exp Zool 228:415-429

Haas LW (1977) The effect of the spring-neap tidal cycle on the vertical salinity structure of the James, York, and Rappahannock rivers, Virginia, U.S.A. Estuar Coast Mar Sci $5: 485-496$ 
Hagerman L, Uglow RF (1985) Effects of hypoxia on the respiratory and circulatory regulation of Nephrops norvegicus. Mar Biol 87:273-278

Hassell MP (1978) The dynamics of arthropod predator-prey systems. Princeton University Press, Princeton, NJ

Hassell MP, May RM (1973) Stability in insect host-parasite models. J Anim Ecol 42:693-736

Hassell MP, May RM (1974) Aggregation of predators and insect parasites and its effect on stability. J Anim Ecol 43:567-594

Hines AH, Comtois KL (1985) Vertical distribution of infauna in sediments of a subestuary of Central Chesapeake Bay Estuaries 8:296-304

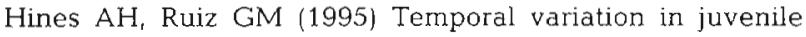
blue crab mortality: nearshore shallows and cannibalism in Chesapeake Bay. Bull Mar Sci 57(3):884-901

Hines AH, Haddon AM, Wiechert LA (1990) Guild structure and foraging impact of blue crabs and epibenthic fish in a subestuary of Chesapeake Bay. Mar Ecol Prog Ser 67:105-106

Holling CS (1959) Some characteristics of simple types of predation and parasitism. Can Entmol 91:385-398

Hurlbert S (1984) Pseudoreplication and the design of ecological field experiments. Ecol Monogr 54:187-211

Jachowski RL (1973) Agonistic behavior of the blue crab Callinectes sapidus Rathbun. Behaviour 50:232-253

Jørgensen BB (1980) Seasonal oxygen depletion in the bottom waters of a Danish fjord and its effect on the benthic community. Oikos 34:68-76

Kapper MA, Stickle WB (1987) Metabolic responses of the estuarine gastropod Thais haemastoma to hypoxia. Physiol Zool 60:159-173

Laughlin RA (1982) Feeding habits of the blue crab, Callinectes sapidus Rathbun, in the Apalachicola Estuary. Florida. Bull Mar Sci 32(4):807-822

Leber KM (1985) The influence of predatory decapods, refuge, and microhabitat selection on seagrass communities. Ecology 66:1951-1964

Lipcius RN, Hines AH (1986) Variable functional response of a márine predator in dissimilar homogenous microhabitats. Ecology 67:361-371

Loesch H (1960) Sporadic mass shoreward migrations of demersal fish and crustaceans in Mobile Bay, Alabama. Ecology 41:292-298

Mansour RA (1992) Foraging ecology of the blue crab, Callinectes sapidus Rathbun, in lower Chesapeake Bay. PhD dissertation, College of William and Mary, Virginia Institute of Marine Science, Gloucester Point

Mansour RA, Lipcius RN (1991) Density-dependent foraging and mutual interference in blue crabs preying upon infaunal clams. Mar Ecol Prog Ser 72:239-246

Martin TH, Wright RA, Crowder LB (1989) Non-additive impact of blue crabs and spot on their prey assemblages Ecology 70(6): 1935-1942

May EB (1973) Extensive oxygen depletion in Mobile Bay, Alabama. Limnol Oceanogr 18(3):353-366

Menge BA (1983) Components of predation intensity in the low zone of the New England rocky intertidal region. Oecologia 58:141-155

Moksnes PO, Lipcius RN, Pihl L, van Montfrans J (1997) Cannibal-prey dynamics in young juveniles and postlarvae of the blue crab. J Exp Mar Biol Ecol 215:157-187

Murdoch WW, Oaten A. (1975) Predation and population stability. Adv Ecol Res 9:1-125

Nestlerode JA, Diaz RJ (1998) Effects of periodic environmental hypoxia on predation of a tethered polychaete, Glycera americana: implications for trophic dynamics. Mar Ecol Prog Ser 172:185-195
Nilsson HC, Rosenberg R (1994) Hypoxic response of two marine benthic communities. Mar Ecol Prog Ser 115 $209-217$

Officer CB, Biggs RB, Taft JL, Cronin LE, Tyler MA, Boynton WR (1984) Chesapeake Bay anoxia: origin, development and significance. Science 223:22-27

Orth RJ, van Montfrans $J$ (1987) Utilization of a seagrass meadow and tidal marsh creek by blue crabs Callinectes sapdius. I. Seasonal and annual variations in abundance with emphasis on post-settlement juveniles. Mar Ecol Prog Ser 41:283-294

Paine R (1980) Food webs: interaction strength and community infrastructure. J Anim Ecol 49:667-685

Palmer AR (1979) Fish predation and the evolution of gastropod shell sculpture: experimental and geographical evidence. Evolution 33:697-713

Pihl L, Baden SP, Diaz RJ (1991) Effects of periodic hypoxia on distribution of demersal fish and crustaceans. Mar Biol 108:349-360

Pihl L, Baden SP, Diaz RJ, Schaffner LC (1992) Hypoxiainduced structural changes in the diet of bottom-feeding fish and Crustacea. Mar Biol 112:349-361

Renaud ML (1986) Detecting and avoiding oxygen deficient seawater by brown shrimp, Penaeus aztecus (Ives), and white shrimp Penaeus setiferus (Linnaeus). J Exp Mar Biol Ecol 98:283-292

Rosenberg R, Hellman B, Johansson B (1991) Hypoxic tolerance of marine benthic fauna. Mar Ecol Prog Ser 79 $127-131$

Sandberg E (1994) Does short-term oxygen depletion affect predator-prey relationships in zoobenthos? Experiments with the isopod Saduria entomon. Mar Ecol Prog Ser 103:73-80

Smith LD, Hines A (1991) The effect of cheliped loss on the blue crab Callinectes sapidus Rathbun foraging rate on soft-shelled clams Mya arenaria L. J Exp Mar Biol Ecol 151:245-256

Sneddon LU, Taylor AC, Huntingford FA (1999) Metabolic consequences of agonistic behavior: crab fights in declining oxygen tensions. Anim Behav 57:353-363

Stickle WB, Kapper MA, Liu L, Gnaiger E, Wang SY (1989) Metabolic adaptations of several species of crustaceans and molluscs to hypoxia: tolerance and microcalorimetric studies. Biol Bull 177:303-312

Taylor J (1998) United States Geological Survey, North Carolina District: Neuse River water quality plots - dissolved oxygen. BB-MER accessed: July-Sepember 1998; available at http://sgildncrlg.er.usgs.gov/

Trevallion A (1971) Studies on Tellina tenuis Da Costa. III. Aspects of general biology and energy flow. J Exp Mar Biol Ecol 7:95-122

Underwood A.J (1981) Techniques of analysis of variance in experimental marine biology and ecology. Oceanogr Mar Biol Annu Rev 19:513-605

Van Engel WA (1958) The blue crab and its fishery in Chesapeake Bay. Commer Fish Rev 20:6-17

Vermeij GJ (1978) Biogeography and adaptation: patterns of marine life. Harvard University Press, Cambridge, MA

Virnstein RW (1977) The importance of predation by crabs and fishes on benthic fauna in Chesapeake Bay. Ecology 58:1199-1217

Williams AB (1984) Shrimps, lobsters, and crabs of the Atlantic coast of the eastern United States, Maine to Florida. Smithsonian Institution Press, Washington, DC

Wooten JT (1994) Predicting direct and indirect effects: an integrated approach using experiments and path analysis Ecology 75(1):151-165 